\title{
RECORDS AND FLOWER PREFERENCES OF MASARID WASPS (HYMENOPTERA: VESPIDAE)
}

\author{
$\mathrm{By}$ \\ Kenneth W. Cooper (Princeton University) \\ and \\ J. Bequaert (Harvard University)
}

The observations which follow on the masarid wasps in Colorado are based largely upon collections made (by $\mathrm{KWC}$ ) in the vicinity of the Science Lodge of the University of Colorado during the interval July 26-August 21, 1949. Additional flower records and information upon eleven species of Pseudomasaris from Arizona, California, Oregon, South Dakota, Texas and Utah, as well as from Colorado, are included (by JB) from previously unpublished notes. All records, therefore, rest on the authority of Dr. J. Bequaert if they are not initialled " $(\mathrm{KWC})$ ".

Science Lodge, it should be remarked, is located at the margin of Arapaho Moraine, below Mount Niwot, approximately eight miles NNW of the town of Nederland, Colorado, at an altitude of 9,528 ft., just three miles East of the Continental Divide. It is thus in the uppermost fourth of Ramaley's "Montane Zone", heavy stands of lodgepole pine characterizing the region. Road margins and clearings were frequently densely populated with flowers very attractive to aculeate Hymenoptera, and collecting could hardly have been better. The varied terrain with predominantly ponderosa pine-Douglas fir forests below, subalpine fir-Engelmann spruce stands and tundra above, all make Science Lodge located in the intermediate lodgepole pine forest ideally situated as a central base for the field naturalist.

The records which follow may be added to those of Bradley (1922) and Bequaert (1929, 1940, 1943). As many of the older records of Pseudomasaris flower preferences are today uncertain because of obvious misidentification of the plant concerned, it is very important that all new records be validated by authority. The 
Penstemon $^{1}$ species recorded from Colorado (by KWC) were all checked or identified by the well known authority on the Scrophulariaceae, Dr. Francis W. Pennell of the Academy of Natural Sciences, Philadelphia, Pa. The Colorado Phacelia were likewise checked by Prof. Robert Prettyman of Butler University. Phacelia sericea and Ph. ramosissima were named by Dr. R. E. Schultes, of Harvard University, from dried specimens. Dr. C. D. Michener supplied the name Phacelia popei for the record of Pseudomasaris texanus, and Dr. J. Bequaert determined the Ph. californica from fresh material.

Of the 11 species mentioned below, the first three are all that are known from Colorado. The Colorado captures are set off from other records in separate paragraphs for ease of reference.

\section{Pseudomasaris (Toryna) vespoides (Cresson)}

Colorado: Hill's Mill (directly above Science Lodge, 10,000 ft.), 1 ô sunning on open, gravelly ground, at 9 AM, July 26 (KWC); Rainbow Lakes, 10,000 ft., $7 \hat{\delta}$ and 6 o at Penstemon alpinus Torr., $11 \mathrm{AM}$ to $4 \mathrm{PM}$, and 1 ô at Penstemon unilateralis Rydb., 9 AM, July 30 (KWC); Gold Hill, 8,300 ft., $1 \hat{o}$ and $2 \&$ at Penstemon alpinus, 8:45 AM, Aug. 6 (KWC); vicinity of Science Lodge, 9,500 ft., 2 q within flowers of Penstemon alpinus, $11: 20$ AM, Aug. 13, and 1 o sunning at road margin, 8 AM, Aug. 14 (KWC); Poudre River Canyon, $9 \hat{\delta}$ (L. D. Anderson); Creede, 8,844 ft. (S. J. Hunter); Pike's Peak, 1 $q$ and $1 \hat{o}$ (L. Bruner); Ute Creek, Sage Flats (L. Bruner); Grand Junction, $1 \hat{o}$ (L. Bruner); La Junta, 1 ㅇ (Lantz); Florissant, at Penstemon sp. (S. A. Rohwer).

Oregon: Hood River, 1 ô (J. Nottingham); Milton, $2 \hat{o}$, June 22, 1938 (K. Gray and J. Schuh); 10 miles West of Bend, $1 \hat{o}$, June 21, 1939 (K. Gray and J. Schuh); Hart Mountain, 1 \% , June 17, 1938 (K. Gray and J. Schuh); Cornucopia, 6,200-7,000 ft., 1 o at Penstemon sp., July 25, 1936 (H. A. Scullen). CaliFornia: Auburn, many $\hat{o} q$ (L. Bruner); San Jacinto Mts., 1 우 (R. M. Beamer) ; Altadena, $2 \hat{o}$ (KWC); Pasadena, 1 o at cultivated Penstemon azurea Benth. (tentative determination by $\mathrm{A}$. $\mathrm{H}$. Sturtevant), June 9, 1945 (KWC). Utah: Provo (T. Spalding). South Daкотa: Custer; Whitewood; Spearfish, 1 ô, July 15, 1924. Wroming: about 10 to 15 miles W. of Cheyenne, on the highway to Laramie, 8,500 ft., Albany Co., August 11, 1949, and August 10,

${ }^{1}$ We follow Pennell (1935, Ac. Nat. Sci. Philadelphia, Monograph 1, p. 200) in using Penstemon, rather than Pentstemon or Pentastemon. 
1950, at Penstemon unilateralis (R. R. Dreisbach); flower determined by Dr. F. W. Pennell; both $q$ and $\hat{o}$ very numerous while the sun was shining, visiting the flowers; none were at the flowers while it was cloudy.

This species is one of the most widely distributed of the genus, being known at present from Oregon, California, Nevada, Wyoming, Idaho, South Dakota, Utah, Colorado, Nebraska, Arizona and New Mexico. Its true foodplants appear to be several species of Penstemon, as discussed elsewhere. In this connection, Cresson (1864) states that Ridings collected Ps. vespoides near Empire City, Colorado, at flowers of "a plant allied to the genus Lobelia, growing abundantly on the roadsides." This was evidently a Penstemon.

The extent of the yellow marking varies greatly. Females from California are often more yellow than those from Colorado, sometimes even showing short yellow longitudinal streaks on the mesonotum before the scutellum. Some females are nevertheless practically colored alike in both geographic regions, so that it does not seem possible to segregate the very xanthic specimens as a distinct geographical subspecies. Moreover the specimen with the greatest extent of yellow is a female from Arizona (White Mesa, Kayenta), which not only has very wide abdominal bands, but also has most of the pronotum, scutellum, postscutellum, propodeum and pleura yellow, curved yellow lines along nearly the entire notauli and side lines near the tegulae on the mesonotum. Such extreme variants are very similar to $\boldsymbol{P s}$. wheeleri. If the need were felt for a special name, they should be called var. robertsoni Cockerell.

2. Pseudomasaris (Pseudomasaris) marginalis (Cresson)

Colorado: Moraine below Hill's Mill, 9,800 ft., 1 i at Phacelia heterophylla Pursh, 10 AM, July 27 (KWC); Rainbow Lakes,

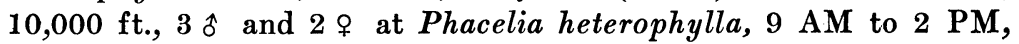
July 30 (KWC); vicinity of Science Lodge, 9,500 ft., 1 \& sunning on open, sandy bank of road, 9:25 AM, Aug. 5 (KWC); Sierra Blanca (L. Bruner); Ute Creek (L. Bruner); Cascade Lodge, Rocky Mountain National Park; Echo Lake, 12,000 ft., 1 우 (R. R. Dreisbach and R. K. Schwab).

Utah: Bear River, North slope of Uinta Mts., 8,000 ft., $2 \hat{o}$ and $3 \%$ at Phacelia sericea (Graham) Gray, June 27, 1949 (F. Werner and W. Nutting).

Known from British Columbia, Alberta, Utah, Colorado and New Mexico. The food plants are species of Phacelia. 


\section{Pseudomasaris (Ps.) zonalis (Cresson)}

Colorado: vicinity of Science Lodge, 9,300 ft., $2 \hat{o}$ and $3 q$ at Phacelia heterophylla Pursh, 7:45 to $11: 30$ AM, July 28, and 2 ô and 1 o at Phacelia heterophylla, 10:15 to 10:45 AM, Aug. 5 (KWC) ; Rainbow Lakes, 10,000 ft., $3 \hat{o}$ at Phacelia heterophylla, 1 PM, July 30 (KWC); Gold Hill, 8,300 ft., 1 \% at Phacelia heterophylla, 8:50 AM, Aug. 6 (KWC); Mont Alto, 8,000 ft., 1 우 at Phacelia heterophylla, 1 PM, Aug. 6 (KWC); Boulder, 19 at Besseya plantaginea (Benth.) Rydb., May 15, 1908 (S. A. Rohwer).

Oregon: Cornucopia, 6,200 to 7,000 ft., 1 \%, July 25, 1936 (R. E. Reider); Mt. Hood, $1 \hat{\delta}$ (J. Nottingham); 5 miles west of Suttle Lake, 1 ô, July 8, 1939 (K. Gray and J. Schuh). California: Lassen National Park, 1 of (C. T. Brues); Emigrant Gap, 1 우 (M. Cazier).

Known at present from British Columbia, Washington, Oregon, California, Nevada, Idaho, Utah, Colorado and Nebraska. The normal foodplants appear to be species of Phacelia and possibly Besseya. Aside from Cresson's (1864) remark that Ridings discovered $P s$. zonalis in August "on a plant most likely to be of the genus Phacelia," the above flower records appear to be the first definite observations on the flower choice of this species. It is of interest that Ridings also found $P s$. marginalis on the same "Phacelia" as Ps. zonalis.

\section{Pseudomasaris (Ps.) occidentalis (Cresson)}

Known from Kansas, New Mexico and Texas. Its only known foodplants are Penstemon.

5. Pseudomasaris (Ps.) coquilletti Rohwer

California: Marsh Creek, Mount Diablo, $1 \hat{o}$ and 1 o at Phacelia californica Cham., April 20, 1949 (R. M. Bohart). ArIzona: Upper Basin, Sabino Canyon, Sa. Catalina Mts., 4 \& at Phacelia ramosissima Dougl., April 22, 1949 (JCB).

Known only from California and Arizona thus far. The foodplants are species of Phacelia and Eriodictyon.

6. Pseudomasaris (Ps.) reheeleri J. Bequaert

California: Yosemite, 1 은 June 12, 1925 (A. L. Melander); Big Pine Creek, Inyo Co., 1 i at Penstemon sp. (R. M. Bohart); Charleton Flats, 6,000 ft., Los Angeles Co., 1 ô and 1 ㅇ (KWC); 
Chilao, 6,000 ft., Los Angeles Co., 1 ㅇ, July 23, 1944 (A. H. Sturtevant).

Known only from California. It seems to use as foodplants both Eriodictyon and Penstemon.

7. Pseudomasaris (Ps.) edwardsii (Cresson)

California: San Jacinto Mts. (R. H. Beamer); Deep Creek, at edge of Mohave Desert, at Eriodictyon tomentosum. UTAH: Eureka.

Known from Washington, California, Nevada and Utah. Visits both Eriodictyon and Phacelia.

\section{Pseudomasaris (Holopticus) texanus (Cresson)}

Texas: Big Bend National Park, Chisos Mts., 3 q at Phacelia popei Torrey and Gray, April 11, 1949 (C. D. Michener and R. M. Beamer).

Typically Ps. texanus has part of the thorax (particularly on the pronotum) and part of the abdomen ferruginous-red; but the extent of this color varies. It is usually more developed in the females, and even in Texas some males are almost without reddish coloration. The other pale markings are decidedly yellowish. Ps. texanus appears to occur only in Texas and New Mexico. The published records from California and Arizona, and probably also those from Utah, should be referred to $P s$. rohweri, which is possibly only a subspecies of texanus (see below). The normal foodplants are most likely species of Phacelia, although there is as yet but one definite observation.

\section{Pseudomasaris $(H$.$) rohweri Bradley$}

California: Westgard Pass, Inyo Co., many $\hat{\delta}$ and $q$, at Phacelia sp., June 18, 1942 (R. M. Bohart). Arizona: Upper Basin, Sabino Canyon, Sa. Catalina Mts., 1 ㅇ at Phacelia ramosissima Dougl., April 22, 1949 (JCB).

Ps. rohweri is known from California and parts of Arizona (the published records of texanus for Tempe, Globe and Phoenix refer to rohweri). Ps. rohweri has been taken at Phacelia only. It is very closely related to $P s$. texanus, differing mainly in the pure white, not yellowish, markings.

10. Pseudomasaris (H.) bariscapus Bradley

More information is urgently needed for this species which is known only from the male holotype collected at Quartzite, Arizona. 
11. Pseudomasaris (H.) phaceliae Rohwer

More information is needed for this species also. It is known only from New Mexico where it was collected attending Phacelia.

\section{References Cited}

BEQUAERT, J.

1929. A new Pseudomasaris from California, with some considerations on the masarid wasps. Psyche 36: 61-88.

1929. Some additional remarks on the masarid wasps. Psyche 36: 364-369.

1940. Notes on the distribution of Pseudomasaris and on the foodplants of the Masaridinae and Gayellinae. Bull. Brooklyn Ent. Soc. 35: $37-45$.

1943. Pseudomasaris in Wyoming and Nebraska. Bull. Brooklyn Ent. Soc. 38: 120.

BradLey, J. C.

1922. The taxonomy of the masarid wasps, including a monograph of the North American species. Univ. California Pub. Ent. 1: 369-464.

Cresson, E. T.

1864. Descriptions of two new species of Masaris. Proc. Ent. Soc. Philadephia 3: 672-678. 

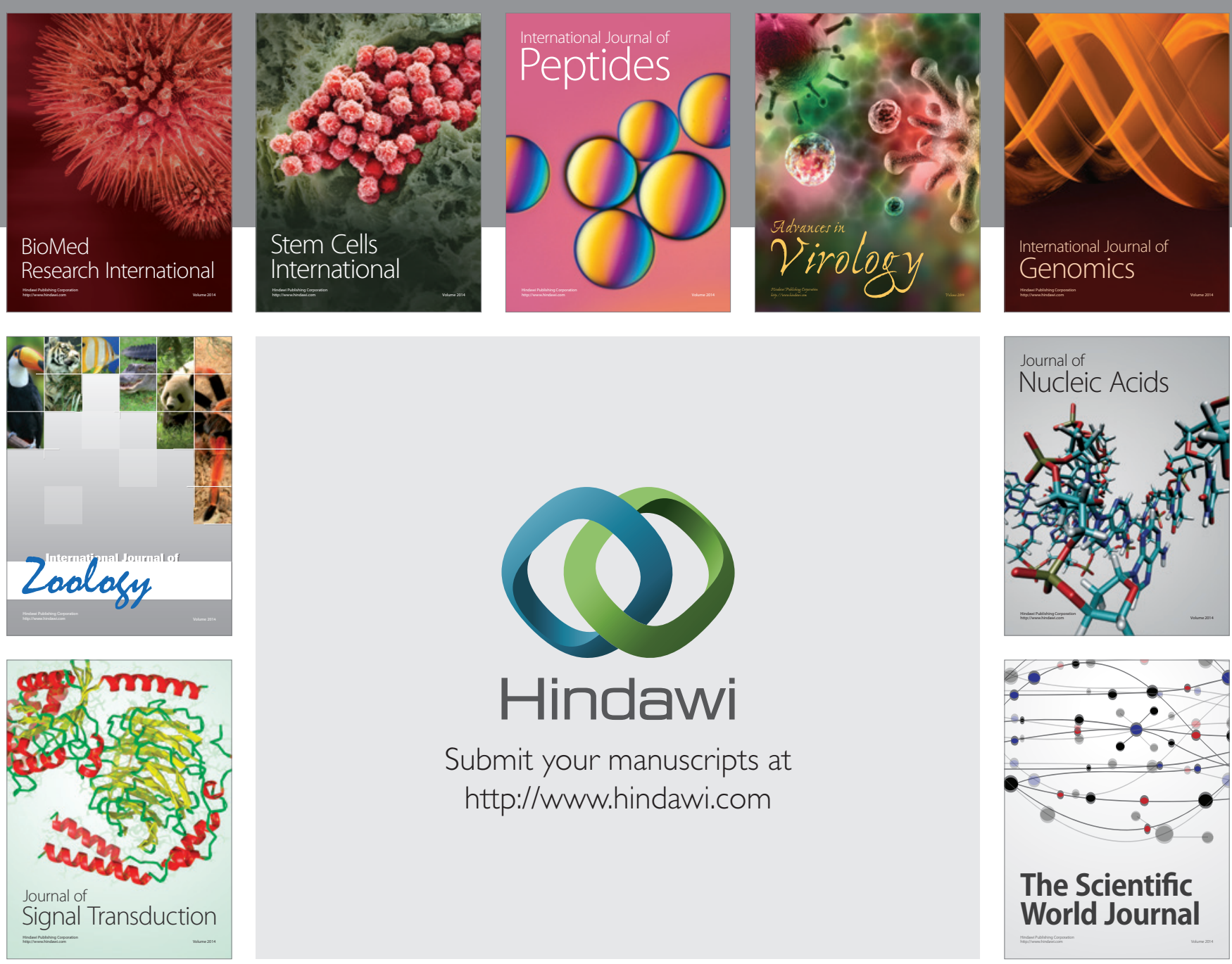

Submit your manuscripts at

http://www.hindawi.com
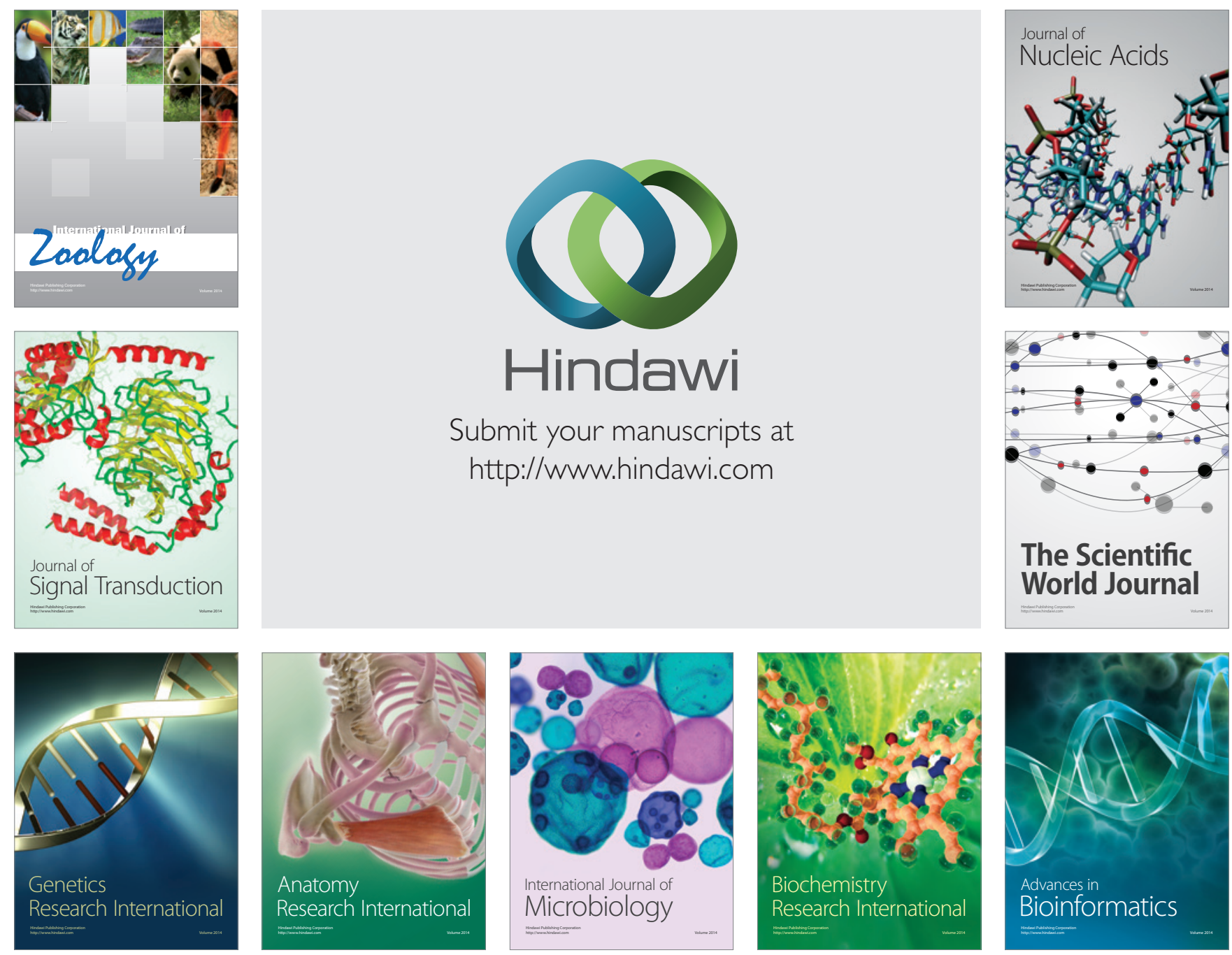

The Scientific World Journal
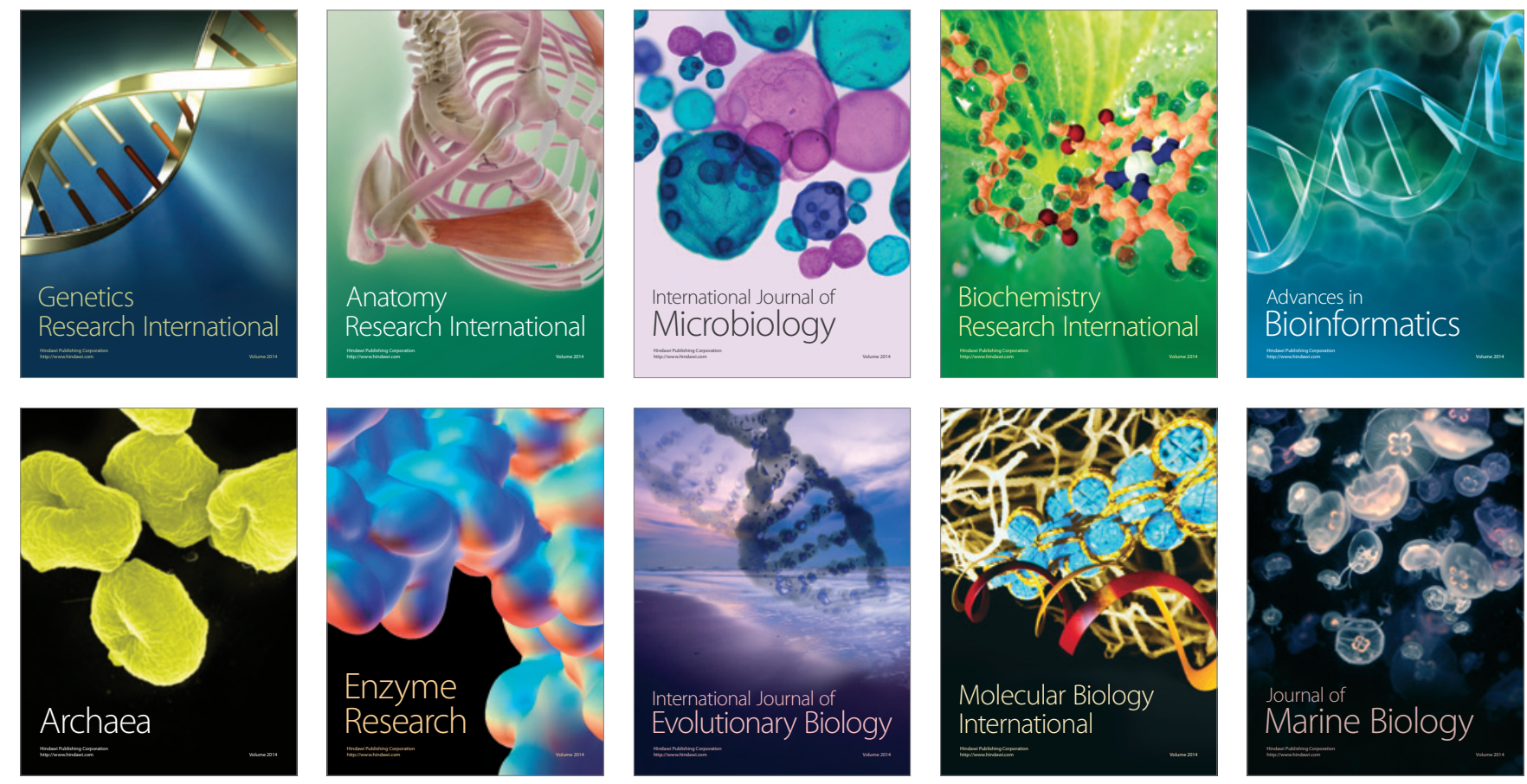